УДК $81 ' 37(=512.36)$

DOI: $10.18101 / 2305-459 X-2020-2-12-16$

\title{
СОЧЕТАЕМОСТЬ МОНГОЛЬСКИХ АНТРОПОНИМОВ В ПИСЬМЕННОМ ПАМЯТНИКЕ «ПРАВДИВЫЕ ЗАПИСИ О МОНГОЛАХ ЦИНСКОЙ ИМПЕРИИ»
}

\author{
(C) Сундуева Екатерина Владимировна \\ главный научный сотрудник, \\ Институт монголоведения, буддологии и тибетологии СО РАН \\ Россия, 670047, г. Улан-Удэ, ул. Сахьяновой, 6 \\ sundueva@mail.ru
}

\begin{abstract}
Аннотация. Автор рассматривает лексемы, сочетающиеся с антропонимами в тексте письменного памятника «Dayičing ulus-un mongyul-un mayad qauli», опубликованного в шести томах в 2013 г. в г. Хух-хото Автономного района Внутренняя Монголия КНР. Большинство данных слов, обозначающих должности, титулы и степень родства, представляют собой историзмы. Ряд из них понятен в настоящее время, значение других непонятно в современном монгольском языке без обращения к специальной литературе. Помимо монгольской лексики среди них представлены заимствования из маньчжурского и китайского языка, в силу исторических условий являвшиеся источником обогащения монгольского языка. Эти слова имеют определенную культурно-историческую значимость, соотносящуюся с важными в духовном отношении явлениями жизни монголов Цинской империи XVII в.

Ключевые слова: старописьменный монгольский язык; письменный памятник; антропоним; лексика; семантика; должность; титул; термин родства; заимствование; историзм.
\end{abstract}

Благодарность: работа выполнена при поддержке РФФИ в рамках научноисследовательского проекта № 18-59-94006 МОКНМ_а «История и культура монгольских народов в период правления императора Канси» (по материалам памятника «Правдивые записи о монголах Цинской империи»).

\section{Для цитирования:}

Сундуева E. B. Сочетаемость монгольских антропонимов в письменном памятнике «Правдивые записи о монголах Цинской империи»// Вестник Бурятского государственного университета. Язык. Литература. Культура. 2020. Вып. 2. С. 12-16.

Данная работа посвящена рассмотрению слов, сочетающихся с антропонимами, представленными в переводе письменного памятника "Dayičing ulus-un mongyul-un mayad qauli”, опубликованного в шести томах в 2013 г. в г. Хух-хото Автономного района Внутренняя Монголия Китайской Народной Республики. Первый том перевода на русский язык был издан Институтом монголоведения, буддологии и тибетологии Сибирского отделения Российской академии наук под названием «Правдивые записи о монголах Цинской империи» в 2019 г. Он включает периоды правления первых трех правителей маньчжурской династии: Нурхаци (годы правления: 1616-1626), Хун-тайджи (годы правления: 1626-1643) и Фулиня (годы правления: 1643-1661). В процессе перевода привлекался также источник на китайском языке “清朝太祖太宗世祖朝实录蒙古史史料抄”, имею- 
E. В. Сундуева. Сочетаемость монгольских антропонимов в письменном памятнике «Правдивые записи о монголах Цинской империи»

щий первостепенное значение при рассмотрении онимической лексики памятника. Так, в связи с одинаковым написанием согласных $t / d$, гласных $a / e$ в монгольском письме личное имя Тэмдэй допускает восемь вариантов прочтения: Тамтай, Тэмтэй, Дамдай, Дэмдэй, Тамдай, Тэмдэй, Дамтай и Дэмтэй, в то время как китайский вариант достаточно ясно представляет звучание антропонима 特木德 tè mù dé.

Текст памятника изобилует антропонимической лексикой, широко представленной в указах о поощрении, повышении и понижении чиновников, передаче титулов по наследству, назначении на должности или смещении с нее. В первом томе перевода зафиксировано свыше 3600 антропонимов, многие из которых используются с названиями титулов, должностей или терминами родства. Наибольшее количество личных имен содержит запись, сделанная в день черной курицы первого весеннего месяца 9-го года правления Сэчэн-хана (1635) и включающая перечень имен 127 чахарских сановников, изъявивших покорность [3, c. 188-189].

В переводе монгольские антропонимы представлены с опорой на письменный источник с сохранением интервокальных согласных $\gamma / g$ (например, Адугучи, Джаяган, Чилагун). Сложные антропонимы даются через дефис, при этом второй компонент имени - с прописной графемы (например, Наму-Сэрэн, ГармаСэвэн). Китайские антропонимы представлены в соответствии с общепринятой системой транскрипции Палладия. Сначала пишется фамилия, после нее - личное имя. Между ними ставится пробел, при этом сложное имя пишется слитно.

Названия должностей, титулов и термины родства, идущие следом за антропонимами, также пишутся через дефис, но со строчной графемы. Следует отметить, что в ряде случаев очень сложно определить, где имя и где титул. Отдельные титулы и должности представлены со строчной графемы, за исключением титулов Тушэту-хан, Сэчэн-хан, Дзасагту-хан и Номун-хан. При наличии антропонима данные титулы пишутся со строчной графемы (например, тушэту-хан $У_{y б} a$ ). Некоторые лексемы могут выступать и как личное имя, и как обозначение титула, должности. Например, Банди функционирует как антропоним: «Аоханскому улус-ун эфу Банди был пожалован титул туру-ин цзюньвана. В благодарность за оказанную милость тот поднес верблюдов и лошадей, но [хан] вернул дары» [3, с. 287]. Также лексема встречается в сочетании с антропонимами Гэндун-банди, Чойр-банди, Шигэджин-банди и выступает в основном значении п.-монг. bandi 'низшая степень буддийского священства' [7, р. 1053], монг. банди 'послушник; первая низшая степень монашества; послушник, принявший обет не убивать, не воровать, не иметь сношений с женщинами, не лгать и не пить вино', кит. 班第 $b \overline{a n}$ dì.

Примечательно, что после пожалования человеку титула накладывался запрет на использование его личного имени, о чем свидетельствует запись, сделанная в день белой лошади первого весеннего месяца 9-го года правления Сэчэн-хана (1635): «В благодарность за благополучную доставку супруги чахарского хана хан наградил чахарского сановника Дони-хулуга лошадью в доспехах. Он пожаловал ему титул дурагал-дархан-нойона, вручив грамоту с печатью, согласно которой он получал право на суточное довольствие при передвижении в пределах государства, право в военном походе следовать впереди, в облавной охоте - в 
середине. Также он освобождался от повинности предоставлять подводу и довольствие из поколения в поколение. [Хан] повелел не называть его настоящим именем, нарушение повлечет наказание» [3, с. 287].

Среди наиболее часто представленных названий должностей, титулов следует отметить следующие: п.-монг. tayiji, tayisi 'визирь или верховный министр; почетный титул первой степени' [7, p. 1551], кит. 台吉 tái jí ‘тайджи, один из феодальных титулов; княжич; дворянин' (251 употребление); п.-монг. поуап 'князь; владыка, повелитель, господин; глава, начальник, предводитель' [7, р, 694], по мнению О. Сүхбаатара, восходящее к кит. lăо уе [5, с. 148] (100 употреблений); п.-монг. ǰayisang 'дзайсанг, управитель отока; родовой глава', кит. 寨桑 zhài sāng (77 употреблений); п.-монг. darqan 'свободный от податей, дворянин' [7, p. 1676], кит. 达尔汉 dá ěr hàn (36 употреблений); п.-монг. јаsayul 'управитель, урядник, распорядитель', кит. 扎苏尔 $z h \bar{a} s \bar{u}$ ěr (32 употребления); п.-монг. qоsiуис̌i 'начальник военной дивизии' [7, p. 906]. С 21 антропонимом встречается титул п.-монг. üiǰeng, монг. үйзэн 'феодальный титул, присваиваемый тайджи'. «Во времена Юаньской империи единица войска, охранявшего ханский дворец, называлась вэй, командир этой единицы - вэй жан. Үйзэн представляет собой монгольскую транскрипцию этого слова» [4, с. 99], кит. 卫征 wèi zhēng. Также представлены монг. хошууч 'начальник передового отряда', кит. 和硕齐 hé shuò qí (19 употреблений); п.-монг. kölüg 'человек неутомимый, непоколебимый, постоянный' [7, р. 2604], монг. хөлөг 'сподвижник, витязь', кит. 虎鲁克 hǔ lǔ kè (14 употреблений); п.-монг. јагуис̆і ‘судья, верховный судья’ [7, р. 2305], кит. 扎 固齐 zhā ěr gù qí (12 употреблений); п.-монг. sigülengge, монг. шүҮлэнгэ 'родовой старшина', кит. 舒冷格 shū lěng gé (5 употреблений); п.-монг. čerbi, монг. чэрви 'высокопоставленное лицо, визирь, придворная должность при дворе Чингисхана', кит. 车尔贝 chēèr bèi (4 употребления).

Привлекает внимание слово п.-монг. durayal (кит. 杜喇尔 dù lă ěr), не представленное в современных монголоязычных словарях (14 употреблений): Батудурагал, Тогтунуй-дурагал, Убаши-дурагал и пр. «Титул встречается в виде дурал, дурар, дурхар. Возможно, он обозначал привилегированных людей. Слово дур также имело значения 'права; власть'. Титул дурал, функционировавший в XVI в., продолжал использоваться в период правления Цинской империи’ [4, с. 43]. C 18 антропонимами используется титул п.-монг. ildeng (кит. 伊尔登 ȳ̄ ěr dēng), который связан не со значением 'меч, сабля, палаш', а с п.-монг. ilde 'без занятия, без должности' [7, р. 306], ср. бур. элдин 'привольный'. «В XV-XVIII вв. слово илдэн являлось эпитетом в титулах» [6, с. 55]. Также в тексте 18 раз встречается древний титул п.-монг. čögekür, монг. цөөөхөр 'звание, близкое к илдэн, хошууч, хөндлөн' [mongoltoli.mn/dictionary/detail/124831]; кит. 绰虎尔 chuò hŭ ěr. Название должности п.-монг. qопуіп 'главный распорядитель на свадебном торжестве' [8, p. 965], монг. хонжин 'чиновник, ответственный за проведение церемоний в период империи Юань' [mongoltoli.mn/dictionary/detail/110077] сопровождает 13 антропонимов. 
E. В. Сундуева. Сочетаемость монгольских антропонимов в письменном памятнике «Правдивые записи о монголах Цинской империи»

Из терминов родства, используемых вместе с антропонимами, чаще всего встречается п.-монг. tabunang 'зять императорский или княжеский' [7, p. 1601], кит. 塔布囊 tă bù náng 'титул княжеского наследника'. По мнению О. Сухбаатара, слово заимствовано из маньчжурского языка [5, с. 177], хотя слово не отмечено в словаре И. Захарова [1]. А. Очир пишет: «Некоторые исследователи считают, что слово тавнан (tabunang) имеет китайское происхождение, без указания его начертания и смыслового значения. Также есть точка зрения о том, что тавнан исходит от числительного тав в монгольском языке: изначально было тавд или тавнад, а потом стало тавнан». Сам же автор предлагает версию, согласно которой, оно образовано из двух слов: монг. tabun 'пять' и кит. 王 wāng 'ван, князь' [2, с. 150-151]. Данный термин родства сопровождает 67 антропонимов: Абатайтабунанг, Анга-табунанг, Аюши-табунанг, Банджур-табунанг и др. Также широко представлен другой маньчжурский термин: п.-монг. efü, кит. 额驸 $e ́ f u ̀$, маньчж. эфу 'большой зять, муж старшей сестры; зять царский и княжеский' [1, c. 91]. Так, в первом томе встречается 30 имен с данным термином: Бадари-эфy, Балдачи-эфу, Банди-эфу, Баясгулан-эфу, Бираши-эфу и пр. 29 антропонимов сочетаются с п.-монг. güyeng, монг. гүен 'титул, который, вероятно, происходит от кит. гуеэ 'зять', по аналогии с 老爷 lăo уе́ $\rightarrow$ нойон' [4, с. 34], кит. 古英 gǔ yīng.

Также с антропонимами используются такие термины родства, как п.-монг. пауасии ‘дядя по материнской линии' (Угшан-нагачу, Ашидархан-нагачу, Сангарджай-нагачу и др.) и п.-монг. dekem-е, от от маньчж. дэхэмэ 'дядя, муж младшей тетки’ [1, с. 801] (Дорджи-дэхэмэ, Очирсан-дэхэмэ). Вызывает интерес частое употребление с антропонимами лексемы п.-монг. tasurqai 'отсеченный' [7, p. 1616], монг. тасархай 'отдельный, обособленный'. Она встречается 9 раз (Дорджи-тасурхай, Джамсу-тасурхай, Мэндухэй-тасурхай и др.), значение слова позволяет предположить, что оно обозначало сына, отделившегося от родительского дома после женитьбы.

Таким образом, среди монгольских слов, сочетающихся с личными именами монголов в XVII в., представлены историзмы, обозначающие названия титулов, должностей, терминов родства. Выявлено, что они являются лексическими кальками соответствующих маньчжурского и китайского языков. Антропонимы привлекают внимание не только лингвистов, но и историков, этнографов, культурологов тем, что могут способствовать восстановлению исторических реалий рассматриваемого периода, содействуя воспроизведению его колорита.

\section{Литература}

1. Захаров И. Полный маньчжурско-русский словарь. СПб.: Тип. Императорской академии наук, $1875.1129 \mathrm{c}$.

2. Очир А. Монгольские этнонимы: вопросы происхождения и этнического состава монгольских народов. Элиста: КИГИ РАН, 2016. 286 с.

3. Правдивые записи о монголах Цинской империи. Т. 1. Правление Тайцзу, Тайцзуна и Шицзу / пер. со старописьм. монг. Е. В. Сундуевой. Иркутск: Оттиск, 2019. $648 \mathrm{c.}$

4. Дайчин гүрний дотоод яамны монгол бичгийн гэрийн данс. Дагалга боть. лаанбаатар: Соёмбо принтинг, 2017. 146 c. 
5. Сүхбаатар О. Монгол хэлний харь үгийн толь. Улаанбаатар: Адмон компани, 1997. $234 \mathrm{c}$.

6. Урангуа Ж. Хэргэм, зэрэг цол өргөмжлөхүй (XVII-XX зууны эхэн). Улаанбаатар: Нарагбулаг принтинг, 2000. 59 с.

7. Kowalewski J. E. Dictionnaire mongol-russe-français. Kasan: Imprimerie de l’Université, 1849. 2690 p.

8. Lessing F. D. Mongolian-English dictionary. Berkeley Los Angeles: University of California Press, 1960. 1217 p.

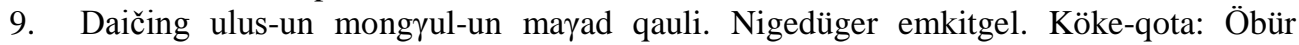

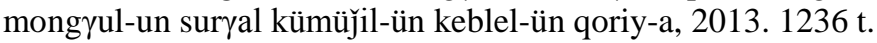

10. 齐木德道尔吉, 巴根那。清朝太祖太宗世祖朝实录蒙古史史料抄。呼和浩特: 内 蒙古大学出版社, 2002。-884 页。

\title{
CO-OCCURRENCE OF MONGOLIAN ANTHROPONYMS \\ IN THE WRITTEN MONUMENT "TRUE RECORDS \\ ABOUT THE MONGOLS OF THE QING EMPIRE"
}

\author{
Ekaterina V. Sundueva \\ Chief Researcher of Linguistics Department, \\ Institute for Mongolian, Buddhist and Tibetan Studies SB RAS \\ 6 Sakhyanovoy St., Ulan-Ude 670047, Russia \\ E-mail: sundueva@mail.ru
}

Abstract. The article considers the lexemes cooccurring with anthroponyms in the text of the written monument "Dayičing ulus-un mongyul-un mayad qauli", published in six volumes in 2013 in Hohhot, Inner Mongolia Autonomous Region of the PRC. Most of these words denoting posts, titles, and kinship are historicisms. A number of these words are comprehensible today, but the meaning of others is difficult to understand in the modern Mongolian language without referring to special literature. In addition to Mongolian words among these lexems there are borrowings from Manchu and Chinese, which historically were a source of enrichment for the Mongolian language. These words have a certain cultural and historical significance associated with the spiritually important phenomena in the life of Mongols of the Qing Empire (the $17^{\text {th }}$ century).

Keywords: old-written Mongolian language; written monument; anthroponym; vocabulary; semantics; post; title; kinship term; borrowing; historicism. 